\title{
Status of the Beach Litter in the UNESCO World Heritage Site of Dungonab and Mukkawar Island Marine National Park in Sudan, Red Sea
}

\author{
Eldirdery Abeadallah Abdelrahman Ibrahim ${ }^{\mathbb{D}},{ }^{1}$ Nahid Abdel Rahim Osman ${ }^{D},{ }^{1}$ \\ and Omar Ali Mohamed Eisa ${ }^{2}$ \\ ${ }^{1}$ Department of Coastal Management, Faculty of Marine Science and Fisheries, Red Sea University, P.O. Box 24, \\ 33311 Port Sudan, Sudan \\ ${ }^{2}$ Department of Marine Protected Areas, Wildife Conservation General Administration, khartoum, Sudan
}

Correspondence should be addressed to Eldirdery Abeadallah Abdelrahman Ibrahim; drdrann@yahoo.com

Received 18 July 2019; Revised 22 October 2019; Accepted 20 November 2019; Published 12 February 2020

Academic Editor: Ram Chander Sihag

Copyright $\odot 2020$ Eldirdery Abeadallah Abdelrahman Ibrahim et al. This is an open access article distributed under the Creative Commons Attribution License, which permits unrestricted use, distribution, and reproduction in any medium, provided the original work is properly cited.

\begin{abstract}
Information on marine litter in general and beach litter in particular from Sudan and to some extent from the Red Sea region is insufficient. The aim of this study is to assess the beach litter composition, distribution, and abundance in some selected beaches of the World Heritage Site of Dungonab Bay and Mukkawar Island National Park (DMNP) located in Sudan, Red Sea coast, and to examine the rate of beach litter flux and the cleanliness of its beaches in order to provide baseline information for beach litter management at DMNP. A total of 6 sites were investigated for beach litter over a 10-month period from January to October 2017 on a quarterly basis. A total of 24 collections of beach litter were performed covering a stretch of $600 \mathrm{~m}$ or $7700 \mathrm{~m}^{2}$ of DMNP coastline. In total, 3037 beach litter items were collected during the study time from DMNP with an overall average of $506.2 \pm 409.8$ items $/ 100 \mathrm{~m}\left(0.4\right.$ items $\left./ \mathrm{m}^{2}\right)$. Plastic beach litter was the most abundant (1738 items), constituting $57.23 \%$ with an average density of $289.7 \pm 242.2$ items $/ 100 \mathrm{~m}\left(0.23\right.$ items $\left./ \mathrm{m}^{2}\right)$. The beaches of DMNP were clean $(\mathrm{CCI}=4.6)$ at the time of the study. The rate of flux of the beach litter decreased steadily from 21.9 to 16.43 items $/ 100 \mathrm{~m} /$ day with an overall average of $18.82 \pm 2.8 \mathrm{items} / 100 \mathrm{~m} /$ day. The gradual decrease in the net accumulation of beach litter over the period of the study suggests that the beach litter at DMNP was likely of a local land-based origin and the beaches of DMNP are not a potential sink of marine litter. The determination of the rate of flux of beach litter is a reasonable indicator of the dynamics of beach litter in DMNP. Accordingly, application of preventive measures accompanied with awareness activities and investment in plastic collection and recycling would further enhance and preserve the present status of beach cleanliness and encourage tourism activities.
\end{abstract}

\section{Introduction}

Beach litter is widely spread throughout the globe, and its impact on coastal ecosystems biodiversity and services is being evidenced by the growing volume of research on this issue [1]. Therefore, it represents a difficult management issue particularly in marine protected areas $[2,3]$. In these areas, littering from visitors significantly degrades the visual amenity of very attractive land and sea escapes imposing huge economic impacts on local economy, coastal tourism, and other key industries such as fisheries $[4,5]$. Eventually, the main purpose of establishing marine protected areas would be undermined.

Beaches of marine national parks and of world heritage sites, even the remotely located ones, are reported to be littered with debris $[5,6]$. For instance, marine debris was found in all beaches surveyed in five coastal National Park Service units in Alaska with plastic representing $60 \%$ of the debris collected [3].

Information on marine litter in general and beach litter in particular from Sudan and to some extent from the Red Sea region is insufficient. Nevertheless, the studies 
performed were undertaken in marine national parks or in recreational beaches. Consequently, the recreational activities were identified as one of the major sources of benthic and beach litter. One study in Obhur beach near Jeddah city of Saudi Arabia recorded that the density of the beach litter was in the range of 1.72 to 12.54 items $/ \mathrm{m}$ [7] and identified recreational activities and fishing as the main source of litter. Also, the density of benthic litter in Aqaba Marine National Park was estimated to range from 1 to 6 items $/ \mathrm{m}^{2}$ with an overall mean density of $2.8 \mathrm{items} / \mathrm{m}^{2}$ [8]. Similar values of marine litter densities were also obtained for coral reef areas along the Jordanian coast of the Gulf of Aqaba with an overall mean density of 2 items $/ \mathrm{m}^{2}$ in 2011 [9]. South of Aqaba, the overall mean densities of the marine litter were about 5 and 3 items $/ \mathrm{m}^{2}$ in 1994 and 1995, respectively [10]. These values are, in particular, the first two, comparable with the average litter densities reported for the countries of the Adriatic and Ionian macroregions which ranged from 0.22 to 2.9 items $/ \mathrm{m}^{2}$ [11]. Records from the Mediterranean Sea showed temporal and special variations in beach litter composition and densities. Nachite et al. [12] reported that the mean litter concentration along the Mediterranean beaches of Morocco had an average value of $390.8 \pm 255.3$ items $/ 100 \mathrm{~m}$, or $0.054 \pm 0.036$ items $/ \mathrm{m}^{2}$ with lower concentrations for rural areas compared to urban areas. In the same line, the study of Asensio-Montesinos et al. [13] from the Spanish Mediterranean coast has indicated that litter abundance and density related to beach users activities recorded in autumn were greater than in spring, particularly at urban and resort beaches.

Along the Sudanese Red Sea coast ( $\geq 750 \mathrm{~km}$ in length), more than 6 marine protected areas with unique marine life components have been proposed or established. Recently, in 2016, Dungonab Bay-Mukkawar Island Marine National Park (DMNP) and Sanganeb Atoll Marine National Park (SAMNP) were inscribed as world heritage sites (WHS) by UNESCO.

Despite the high ecological and socioeconomic value of DMNP, its coastal area is visibly littered with solid wastes even in its remote beaches where no settlements are found. Beaches and mangrove stands are noticeably polluted with plastic wastes and, to a lesser degree, other kinds of solid waste despite the fact that Sudanese Red Sea coast is sparsely and lightly inhabited. This situation could possibly be aggravated by the expected increase in visitor numbers to DMNP as a world heritage site.

This study is meant to contribute to the understanding of the nature and scale of the beach litter issue at DMNP in order to provide evidence-based information for its management and for the sustainability of the DMNP as WHS.

The aim of this study was to assess the beach litter composition, distribution, and abundance in some selected beaches in the WHS of DMNP and to evaluate the cleanliness of its coasts in order to provide baseline information for beach litter management at DMNP.

\section{Materials and Methods}

2.1. Study Area. DMNP is one of the two marine protected areas established in the Red Sea State (Sudan), in 2004, and was inscribed as a WHS in 2016 for its outstanding marine biodiversity and cultural values. The southern boundary of DMNP is approximately $125 \mathrm{~km}$ north of Port Sudan harbour. DMNP's total area is around $2800 \mathrm{~km}^{2}$, of which $800 \mathrm{~km}^{2}$ is coastal land and $2000 \mathrm{~km}^{2}$ is seawater. The MPA extends a straight-line distance of approximately $70 \mathrm{~km}$ north-south and slightly over $40 \mathrm{~km}$ east-west at its widest point. The total length of the coastline in DMNP, including Dungonab Bay and Peninsula and the major islands, is over $200 \mathrm{~km}$.

Dungonab Bay is a shallow water basin partially enclosed by the long, narrow spit of Dungonab Peninsula. Dungonab Bay is approximately $13 \mathrm{~km}$ across at its southern end and extends $31 \mathrm{~km}$ from north to south, enclosing a total area of $284.5 \mathrm{~km}^{2}$. Mukkawar is an uninhibited rocky island (c. $100 \mathrm{~m}$ ) located $30 \mathrm{~km}$ offshore of Dungonab Peninsula.

DMNP is located in a remote rural area, sparsely inhibited with a population of around 2000 people living in several small villages, most of which are located upland. Dungonab and Mohamed Gol villages are the main coastal settlements within DMNP boundaries. The major economic activity is artisanal fishing complemented with other artisanal practices such as sea shell gleaning and animal husbandry.

2.2. Sampling Sites. Six sites (Table 1 and Figure 1) with different types and level of human activities were sampled. The sites were selected to represent most of the coastline of DMNP with due care to site accessibility, exposure degree, and usage/activities. Most beaches in DMNP are sandy to sandy/muddy backed by cliffs in the northern parts or dunes in the southern parts.

2.2.1. Shanaab Bay. Shanaab Bay is located very close to the northern outer boundary of DMNP, and it has a high aesthetic value for the tourism industry. It is known as a nurture place of unique aggregations of dugong due to the extensive seagrass meadows and the tranquility of the site. The beach is sandy, roughly $20 \mathrm{~m}$ in width, backed by dunes and cliffs in some spots. It has been estimated that around 200 peoples live in Shanaab and most of them are fishers.

2.2.2. DokanAlyamani. DokanAlyamani is a very popular spot within Shanaab Bay. It is a camping and landing site for both local and amateur fishers who access fishing ground north of DMNP. The beach is $\geq 20 \mathrm{~m}$ in width backed by a sabkha. No permanent settlement exists around the site.

2.2.3. Dungonab Village. Dungonab Village is located at about $165 \mathrm{~km}$ north of Port Sudan harbour within Dungonab Bay. It accommodates about 97 houses with around 800 persons and most of them are fishers. Sand/muddy beaches are common along the flat coast of the village except at the mouths of the seasonal streams where muddy beaches are common. The width of the beach varies from 5 to $11 \mathrm{~m}$. The village is underprivileged in some basic services including the waste management system; therefore, waste 
TAвLe 1: General characteristics of beach litter sampling sites at DMNP.

\begin{tabular}{lcccc}
\hline Site name & Site code & Beach nature & Major activities & Reference point \\
\hline Shanaab & SH & Remote/natural & Fishing & $\mathrm{N}: 21^{\circ} 20^{\prime} 19.1^{\prime \prime} \mathrm{E}: 37^{\circ} 01^{\prime} 438^{\prime \prime}$ \\
DokanAlyamani & $\mathrm{DY}$ & Remote/semirural & Fishing, recreational camping & $\mathrm{N}: 21^{\circ} 21^{\prime} 05.74^{\prime \prime} \mathrm{E}: 37^{\circ} 02^{\prime} 20.75^{\prime \prime}$ \\
Dungonab Village & $\mathrm{DV}$ & Semirural & Residences, fishing & $\mathrm{N}: 21^{\circ} 06^{\prime} 29.12^{\prime \prime} \mathrm{E}: 37^{\circ} 07^{\prime} 11.02^{\prime \prime}$ \\
Cleaning Area & $\mathrm{CA}$ & Semirural & No activity & $\mathrm{N}: 21^{\circ} 05^{\prime} 9.88^{\prime \prime} \mathrm{E}: 37^{\circ} 07^{\prime} 44.15^{\prime \prime}$ \\
Toytoy & TOY & Remote/natural & Shell gleaning, picnicking & $\mathrm{N}: 20^{\circ} 57^{\prime} 11.13^{\prime \prime} \mathrm{E}: 37^{\circ} 08^{\prime} 36.09^{\prime \prime}$ \\
Mohammed Gol Jetty & MGJ & Semirural & Residence, fish landing site & $\mathrm{N}: 20^{\circ} 54^{\prime} 3.68^{\prime \prime} \mathrm{E}: 37^{\circ} 09^{\prime} 30.12^{\prime \prime}$ \\
\hline
\end{tabular}

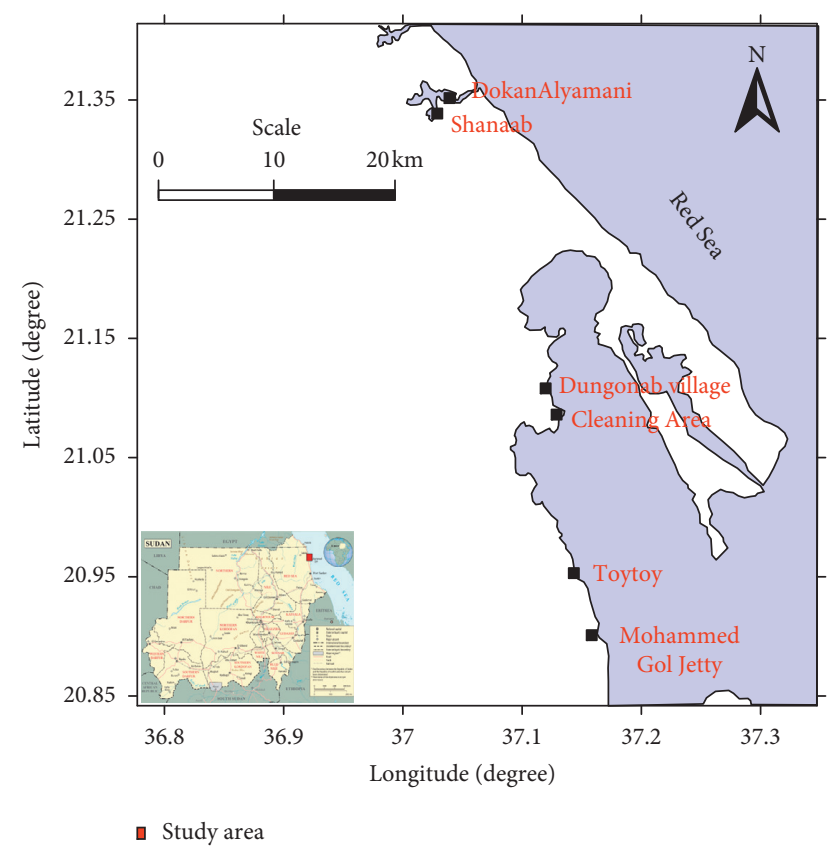

FIGURE 1: Beach litter sampling sites in DMNP, Red Sea State, Sudan.

generated is dump on the ground in the open spaces. Nevertheless, the village has recently become a popular visitor's site for Port Sudan and some of the Khartoum residents who come for fishing or holidays.

2.2.4. Cleaning Area. Cleaning Area is located at the downstream of Dungonab Village where the Pearl Oyster Company is used to clean the oyster shells. The beach is flat and sandy extending $8 \mathrm{~m}$ at its widest point. The area has been deserted for more than 10 years.

2.2.5. Toytoy. Toytoy embayment is an uninhibited picnic site located north of Mohamed Gol village. The site has an attractive sea escape with a sandy beach $\geq 15 \mathrm{~m}$ in width.

2.2.6. Mohamed Gol Jetty. Mohamed Gol Jetty is situated at the old location of Mohamed Gol village which has been relocated upland about $3 \mathrm{~km}$ north of the jetty. The village is approximately inhabited with 720 people; most of them are fishers still using the jetty as a landing site. The site is located at the mouth of a seasonal stream and backed with salt marsh vegetation. The beach is flat, extending for about $10 \mathrm{~m}$, and the sediment is generally of fine sand texture.

\section{Methods}

The guidelines for coastal marine litter assessment described in PERSGA [14] were followed to design the overall methodological framework. Sampling was performed by the same team throughout the study to ensure sampling objectivity.

A total of 6 sites were investigated for beach litter over a 10-month period from January to October 2017. Each station was sampled on a quarterly basis 4 times every 3 months. In total, 24 collections of beach litter were performed covering a stretch of $600 \mathrm{~m}$ or $7700 \mathrm{~m}^{2}$ of DMNP coastline.

3.1. Composition and Density of Beach Litter. At the beach of each site, the start and end points of a stretch of $100 \mathrm{~m}$ in length parallel to the water line were marked with short PVC tubes hammered in the sand. These points were placed immediately above the high water mark as indicated by the strandline. The width of each sampling unit was also measured toward the back of the beach which is determined by natural features such as cliffs or salt marsh vegetation. A reference point at the start of the sampling area was taken with GPS. All beach litter items falling within the range of 0.5 to $\geq 2 \mathrm{~cm}$ in its longest dimension present within the sampling area were collected, sorted, counted, cleaned of adhering sand, dried if required, and weighed. Litter collected was sorted into 10 categories (plastics, fishing gears, metals, glass, wood, textile, food wrappers/pack, cigarette butts, cigarette lighters, and others). The category of others included the following: cartoons, paper bags, paper cups, paper plates, tobacco backing/wrap, paint brush, battery, palm basket, devices, and building materials. Beach litter densities, weights, and percentages were calculated per $100 \mathrm{~m}$ stretch and per unit area $\left(\mathrm{m}^{2}\right)$.

3.2. Rate of Flux. The rate of beach litter flux at the beaches of DMNP was determined as outlined by Cheshire et al. [15] for the study period ( 9 months, 273 days), i.e., the amount of litter arriving at a given length of cleaned beach over a given period of time expressed as (unit quantity of litter) per (unit length of beach) per (unit time).

3.3. Coast Cleanliness Index (CCI). Cleanliness of DMNP beaches was assessed following the method of assessing 
beach cleanliness described in Alkalay et al. [16] who developed the Clean Coast Index (CCI) which is estimated as follows: $\mathrm{CCI}=\mathrm{C}_{\mathrm{M}} * K$, where $C_{\mathrm{M}}$ is the density of plastic litter items per $\mathrm{m}^{2}$ and $K$ is a constant that equals to 20 .

The assessment of the cleanliness of DMNP beaches was based on the CCI scale (0 to 2 indicate very clean beaches, 2-5 clean, 5-10 moderately clean, 10-20 dirty, and >20 extremely dirty).

\section{Results}

The composition of beach litter in the study sites is shown in Table 2. Plastics (57.23\%), processed/worked wood (12.6\%), and fishing gears $(8.5 \%)$ were, respectively, the most abundant litter in DMNP. Textile (5.5\%) was the fourth abundant marine litter class, followed by food wrapper/pack (3.9\%) and metals (3.4\%).

The composition, abundance, and distribution of beach litter varied between the study's sites (Table 3). Plastics, wood, food wrapper/pack, and cigarette butts were recorded in all study sites (Table 3). However, fishing gears, metal, and textile were not found in Shanaab, whereas metal, glass, and textile were not recorded in the Cleaning Area. Though Toytoy beach contained all the beach litter classes examined in this study, their densities were comparatively low (167 items/100 m).

The weight (litter mass) of the total beach litter collected from the individual sites varied considerably from 12.1 to $333.96 \mathrm{~kg} / 100 \mathrm{~m}$ (Table 3). The total mass of the litter collected was $369.25 \mathrm{~kg} / 100 \mathrm{~m}$.

In total, 3037 beach litter items were collected during the study time (Jan to Oct 2017) from DMNP (Table 4). The abundance of total beach litter varied between and within the 6 sites surveyed. With regard to the density of beach litter, the highest value was recorded in Mohamed Gol Jetty $(940 \pm 146.8$ items $/ 100 \mathrm{~m})$, Dungonab Village $(895 \pm 82.8$ items $/ 100 \mathrm{~m})$, and DokanAlyamani (797 \pm 146.3 items/ $100 \mathrm{~m}$ ), respectively (Table 4).

The lowest beach density in $100 \mathrm{~m}$ stretch of the beaches surveyed were recorded for the Cleaning Area (101 items/ $100 \mathrm{~m}$ ), Shanaab (137 items/100 m), and Toytoy (167 items/ $100 \mathrm{~m}$ ), respectively. Individual site beach litter density per unit area varied from a minimum of $0.048 \mathrm{items} / \mathrm{m}^{2}$ at Shannab and the Cleaning Area to a maximum of 1.3 items/ $\mathrm{m}^{2}$ at Mohamed Gol Jetty with an overall density of 0.4 items $/ \mathrm{m}^{2}$ for DMNP.

Similarly, the density of plastic litter (1738 items) varied remarkably from 46 to 560 items $/ 100 \mathrm{~m}$ with an overall average of $289.7 \pm 242.2$ items $/ 100 \mathrm{~m}$ for DMNP. Plastic beach litter represented $57.23 \%$ of the total beach litter collected from DMNP and formed a remarkable amount of the beach litter collected at Shanaab (70.1\%), though the overall density of the beach litter of this site was comparatively low (137 items $/ 100 \mathrm{~m})$. The lowest plastic volume (43.11\%) was reported at Toytoy.

Generally, the beaches of DMNP were clean at the time of the study (Table 5). In line with the composition and density of beach litter, the individual beaches of DMNP were very clean (Shanaab, Toytoy, and Cleaning Area) moderately clean (DokanAlyamani), and dirty (Dungonab Village and Mohamed Gol Jetty).

4.1. Rate of Flux. The accumulation of beach litter at DMNP decreased steadily during the study from 21.9 to 16.43 items/ $100 \mathrm{~m} /$ day with an overall average of $18.83 \pm 2.8$ items each day in $100 \mathrm{~m}$ stretch of beach (Table 6). In contrast to this, accumulation of litter on individual beaches fluctuated over the study period except for Dungonab Village where an apparent decrease in litter accumulation was evident. The minimum rate of beach litter accumulation was recorded at the Cleaning Area $(0.28 \pm 0.15$ items $/ 100 \mathrm{~m} /$ day $)$, and the maximum rate was that of Dungonab Village $(6.52 \pm 2.5 \mathrm{items} / 100 \mathrm{~m} /$ day $)$.

\section{Discussion}

In general, the composition of beach litter in DMNP is fairly comparable to the composition of beach litter reported for other coastal areas such as Aqaba [8] and the Turkish Sarayköy Beach [17]. In this study, plastics were the most abundant litter recorded from all study sites and this is in agreement with previous reports $[11,13,18,19]$.

At the time of this study, the top beach litter categories in DMNP were plastics, wood, fishing gears, and textile, respectively. These litters seem to originate from land-based activities of DMNP residents and visitors. Due to absence of proper landfills, dumped waste eventually reaches the marine environment with surface runoff. Processed/worked wood fragments seem to originate from the ongoing gradual replacement of wooden fishing boats by fiberglass ones as well as the changeover from wood as housing building material to concrete. Consequently, the present ranking of wood as a beach litter category in DMNP may probably differ sometime in the future. In fact, it is likely that the presence of wood as a beach litter with remarkable density at the beaches near the major settlement in DMNP is an indication of the changes in the living conditions at DMNP. Similarly, the present abundance of food wrapper/pack and cigarette butts could also be considered as an indication of future socioeconomic changes in DMNP. These items are considered as an indication of community consumption culture [20] and visitors regularity [2,7]. Both items were the top two beach litter items reported by the Ocean Conservancy in 2017 coastal clean-up campaigns [21].

The overall average density of beach litter in DMNP is comparable with those reported for beach litter from the Mediterranean as recorded by Vlachogianni et al. [11]. For instance, this is comparable with the average densities in Ipsos and Thesprotia (Greece) with the average number of items being 455 items $/ 100 \mathrm{~m}\left(0.91\right.$ items $\left./ \mathrm{m}^{2}\right)$ and 426 items/ $100 \mathrm{~m}\left(0.43\right.$ items $\left./ \mathrm{m}^{2}\right)$, respectively, Bele Skale (Slovenia) with $490 \mathrm{items} / 100 \mathrm{~m}\left(0.49 \mathrm{items} / \mathrm{m}^{2}\right)$, and Neretva (Croatia) with 479 items $/ 100 \mathrm{~m}\left(0.48\right.$ items $\left./ \mathrm{m}^{2}\right)$. Furthermore, the average litter densities of the beaches under investigation (25.3 to 235 items $/ 100 \mathrm{~m}$ ) were also comparable with those reported by Vlachogianni $[6,11]$ for some beaches in the Mediterranean Sea. However, this comparison should be 
TABLE 2: Contribution of litter categories $(n=24$; average \pm SE) to the overall content of beach litter in DMNP.

\begin{tabular}{lcccc}
\hline No. & Litter categories & Density $(\mathrm{N} / 100 \mathrm{~m})$ & Weight $(\mathrm{kg} / 100 \mathrm{~m})$ & Percent $(\%)$ \\
\hline 1 & Plastics & $289.7 \pm 242.2$ & $26.33 \pm 27.64$ & $32.3 \pm 43.7$ \\
2 & Processed wood & $63.7 \pm 50.4$ & $12.03 \pm 11.9$ & 12.6 \\
3 & Fishing gears & $51.4 \pm 28.1$ & $17.3 \pm 30.5$ & 8.5 \\
4 & Textile & $41.5 \pm 59.8$ & $10.6 \pm 15.8$ & 5.5 \\
5 & Metals & $25.8 \pm 25.83$ & $0.8 \pm 0.61$ & 3.4 \\
7 & Food wrapper/pack & $19.5 \pm 14.95$ & $0.1 \pm 0.16$ & 1.9 \\
8 & Cigarette butts & $8.5 \pm 13.71$ & $1.34 \pm 1.43$ & 1.02 \\
9 & Glass & $6.2 \pm 7.7$ & $0.01 \pm 0.02$ & 0.2 \\
10 & Cigarette lighters & $0.8 \pm 2.04$ & $35.07 \pm 3.5$ & 6.2 \\
11 & Others & $31.2 \pm 51.8$ & & \\
\hline
\end{tabular}

TABle 3: Composition and density of beach litter in DMNP $(n=4 /$ site $)$.

\begin{tabular}{|c|c|c|c|c|c|c|c|c|c|c|c|c|}
\hline \multirow{2}{*}{$\begin{array}{l}\text { Beach } \\
\text { Litter items }\end{array}$} & \multicolumn{2}{|c|}{$\mathrm{SH}$} & \multicolumn{2}{|c|}{ DY } & \multicolumn{2}{|c|}{ DV } & \multicolumn{2}{|c|}{$\mathrm{CA}$} & \multicolumn{2}{|c|}{ TOY } & \multicolumn{2}{|c|}{ MGJ } \\
\hline & $\begin{array}{c}\mathrm{N}(\text { item/ } \\
100 \mathrm{~m})\end{array}$ & $\begin{array}{l}\mathrm{W}(\mathrm{kg} / \\
100 \mathrm{~m})\end{array}$ & $\begin{array}{c}\mathrm{N}(\text { item/ } \\
100 \mathrm{~m})\end{array}$ & $\begin{array}{l}\mathrm{W}(\mathrm{kg} / \\
100 \mathrm{~m})\end{array}$ & $\begin{array}{c}\mathrm{N}(\text { item/ } \\
100 \mathrm{~m})\end{array}$ & $\begin{array}{l}\text { W (kg/ } \\
100 \mathrm{~m})\end{array}$ & $\begin{array}{c}\mathrm{N}(\text { item/ } \\
100 \mathrm{~m})\end{array}$ & $\begin{array}{l}\text { W (kg/ } \\
100 \mathrm{~m})\end{array}$ & $\begin{array}{c}\mathrm{N}(\text { item/ } \\
100 \mathrm{~m})\end{array}$ & $\begin{array}{l}\mathrm{W}(\mathrm{kg} / \\
100 \mathrm{~m})\end{array}$ & $\begin{array}{c}\mathrm{N} \text { (item/ } \\
100 \mathrm{~m})\end{array}$ & $\begin{array}{l}\mathrm{W}(\mathrm{kg} / \\
100 \mathrm{~m})\end{array}$ \\
\hline Plastics & 96 & 2.76 & 513 & 22.15 & 451 & 143.23 & 46 & 3.53 & 72 & 10.38 & 560 & 77.47 \\
\hline $\begin{array}{l}\text { Fishing } \\
\text { gears }\end{array}$ & - & - & 83 & 8.03 & 73 & 32.06 & 40 & 7.03 & 12 & 0.85 & 49 & 12.25 \\
\hline Metal & - & - & 23 & 3 & 63 & 34.18 & - & - & 11 & 4.66 & 6 & 0.5 \\
\hline $\begin{array}{l}\text { Processed } \\
\text { wood }\end{array}$ & 25 & 7.55 & 78 & 6.2 & 110 & 52 & 3 & 1 & 36 & 13.5 & 130 & 113.16 \\
\hline Glass & 1 & 0.5 & 8 & 3.5 & 19 & 2.05 & - & - & 1 & 0.05 & 2 & 0.5 \\
\hline Textile & - & - & 17 & 1.73 & 131 & 63 & - & - & 8 & 1.1 & 10 & 3.21 \\
\hline $\begin{array}{l}\text { Food } \\
\text { wrapper/ } \\
\text { pack }\end{array}$ & 4 & 1.07 & 34 & 1.06 & 24 & 0.12 & 7 & 0.6 & 9 & 0.04 & 39 & 1.62 \\
\hline $\begin{array}{l}\text { Cigarette } \\
\text { butts }\end{array}$ & 1 & 0.02 & 35 & 0.43 & 1 & 0.02 & 1 & 0.02 & 1 & 0.02 & 12 & 0.1 \\
\hline $\begin{array}{l}\text { Cigarette } \\
\text { lighters }\end{array}$ & 0 & 0 & 0 & 0 & 0 & 0 & 0 & 0 & 0 & 0 & 5 & 0.05 \\
\hline Others & 10 & 0.2 & 6 & 11.41 & 23 & 6.85 & 4 & 0.09 & 17 & 7.15 & 127 & 8.57 \\
\hline Total & 137 & 12.1 & 797 & 57.51 & 895 & 333.96 & 101 & 12.27 & 167 & 37.75 & 940 & 215.66 \\
\hline
\end{tabular}

SH: Shanaab Bay; DY: DokanAlyamani; DV: Dungonab Village; CA: Cleaning Area; TOY: Toytoy; MGJ: Mohamed Gol Jetty.

TABLE 4: Densities of beach litter and plastic beach litter in DMNP $(n=4$, average \pm SE).

\begin{tabular}{lcccccccc}
\hline No. & $\begin{array}{c}\text { Site } \\
\text { code }\end{array}$ & $\begin{array}{c}\text { Litter }(\text { item/ } \\
100 \mathrm{~m})^{\mathrm{a}}\end{array}$ & $\begin{array}{c}\text { Average litter } \\
(\text { item } / 100 \mathrm{~m})^{\mathrm{e}}\end{array}$ & $\begin{array}{c}\text { Litter density } \\
\left(\text { item } / \mathrm{m}^{2}\right)\end{array}$ & $\begin{array}{c}\text { Plastic density } \\
(\text { item } / 100 \mathrm{~m})^{\mathrm{a}}\end{array}$ & $\begin{array}{c}\text { Average plastic } \\
(\text { item } / 100 \mathrm{~m})^{\mathrm{e}}\end{array}$ & $\begin{array}{c}\text { Plastic } \\
(\%)\end{array}$ & $\begin{array}{c}\text { Plastic density } \\
\left(\text { item } / \mathrm{m}^{2}\right)\end{array}$ \\
\hline 1 & SH & 137 & $35.25 \pm 27.91$ & 0.07 & 96 & $24 \pm 18.1$ & 70.1 & 0.048 \\
2 & DY & 797 & $199.25 \pm 146.3$ & 0.4 & 513 & $128.25 \pm 93$ & 64.4 & 0.26 \\
3 & DV & 895 & $223.75 \pm 82.8$ & 1.25 & 451 & $112.75 \pm 36.34$ & 60.44 & 0.6 \\
4 & CA & 101 & $25.3 \pm 33.37$ & 0.144 & 46 & $11.5 \pm 13.9$ & 45.54 & 0.07 \\
5 & TOY & 167 & $41.75 \pm 24$ & 0.111 & 72 & $18 \pm 8.8$ & 43.11 & 0.048 \\
6 & MGJ & 940 & $235 \pm 146.8$ & 1.3 & 560 & $140 \pm 89.11$ & 59.6 & 0.745 \\
7 & DMNP & $\mathbf{3 0 3 7}$ & $\mathbf{5 0 6 . 2} \pm \mathbf{4 0 9 . 8}$ & $\mathbf{0 . 4}$ & $\mathbf{1 7 3 8}$ & $\mathbf{2 8 9 . 7 \pm 2 4 2 . 2}$ & $\mathbf{5 7 . 2 3}$ & $\mathbf{0 . 2 3}$ \\
\hline
\end{tabular}

SH: Shanaab Bay; DY: DokanAlyamani; DV: Dungonab Village; CA: Cleaning Area; TOY: Toytoy; MGJ: Mohamed Gol Jetty.

taken with some caution considering the environmental, cultural, and socioeconomic differences between the two coastal regions of the Red Sea and the Mediterranean Sea with regard to coastal population size, urbanization, river inputs, economic growth, and frequency of beach clean-up events. However, it should be taken into account that this is the first time ever to collect and assess beach litter in DMNP, so the present values of the densities of beach litter in DMNP may represent the litter that had accumulated for many years.
Generally, the litter mass followed the same trend of litter abundance, i.e., high litter masses were recorded from beaches with high litter abundance. Differences in litter weights could be attributed to the difference in litter materials. For example, the weight of plastics litter items varied considerably according to the type of plastic regardless of the quantity collected.

The remarkable density of beach litter in DokanAlyamani reflects the ongoing recreational activities in the site. This is in agreement with Kitto et al. [7], Jayasiri et al. [22], 
TABLE 5: Cleanliness classification of DMNP beaches based on plastics density (item $/ \mathrm{m}^{2}$ ).

\begin{tabular}{lccc}
\hline No. & Beach name & Clean coast index & Cleanliness \\
\hline 1 & Shanaab Bay & 0.96 & Very clean \\
2 & DokanAlyamani & 7.8 & Moderately clean \\
3 & Dungonab Village & 12 & Dirty \\
4 & Cleaning Area & 1.4 & Very clean \\
5 & Toytoy & 0.96 & Very clean \\
6 & Mohamed Gol Jetty & 15 & Dirty \\
7 & DMNP & 4.6 & Clean \\
\hline
\end{tabular}

TABle 6: Beach litter rate of flux (item/100 m/day) in DMNP.

\begin{tabular}{lccccc}
\hline \multirow{2}{*}{ No } & \multirow{2}{*}{ Beach name } & \multicolumn{3}{c}{ Rate of flux } & Average rate of \\
& & April & July & October & flux \\
\hline 1 & Shanaab Bay & 0.7 & 0.8 & 0.6 & $0.7 \pm 0.1$ \\
2 & DokanAlyamani & 4.7 & 3 & 5.03 & $4.24 \pm 1.08$ \\
3 & Dungonab & 9 & 6.53 & 4.03 & $6.52 \pm 2.5$ \\
4 & Village & & & & $0.28 \pm 0.15$ \\
5 & Cleaning Area & 0.3 & 0.43 & 0.13 & $1.7 \pm 0.62$ \\
6 & Toytoy & 1.9 & 2.2 & 1 & $5.38 \pm 0.22$ \\
7 & Mohamed Gol & 5.33 & 5.2 & 5.63 & $\mathbf{1 8 . 8 2} \pm \mathbf{2 . 8}$ \\
\hline
\end{tabular}

and Nachite et al. [12] who reported that coastal recreational activity produces most of the beach litter. The beach litter in DokanAlyamani represented $26.24 \%$ of the total litter in DMNP, while that of Mohamed Gol Jetty and Dungonab Village represented $30.9 \%$ and $29.5 \%$, respectively, of the total litter volume. This may probably suggest that temporal activities such as recreational fishing could generate significant amount of litter comparable to that produced by continued activities. Therefore, special waste management measures should be undertaken to manage beach litter in these sites particularly in those within the boundaries of marine protected areas.

The lowest density of beach litter was recorded in the Cleaning Area. It is highly likely that these litter items were transported by wind and/or sea currents to the site from the village of Dungonab due to absence of any human activity in the place. Transportation of litter by wind and by surface sea currents is extensively documented [19, 23-25]. This is supported by the vast reduction in the total litter items collected in the successive sampling from 75 items $/ 100 \mathrm{~m}$ in the first time to only 9 items $/ 100 \mathrm{~m}$ in the next sampling after 3 months.

Beach litter density per unit area in DMNP beaches seems to be lower than those reported for a selected beach in the Southeastern Black Sea $\left(1.22-4.17\right.$ items $\left./ \mathrm{m}^{2}\right)$ recorded by Aytan et al. [17]. Once more this comparison should recognize the socioeconomic and cultural differences between the two regions.

The comparatively low percentage of plastic litter obtained here does not entirely corroborate with the extensively reported dominance of plastics $(70 \%$ to $100 \%)$ in beach litter recorded from around the globe [26-28]. This may propose that plastic litter may not necessarily form the major constituent of beach litter in rural remote areas such as DMNP as has been reported in some studies $[17,29]$. In such low-income areas, most of the solid waste in general and in particular some plastic waste are reused by the community in different ways depending on the type and form of the plastic litter item. For example, plastic water bottles are collected and reused as a container to sell small volumes of cooking oil, home-made ghee, camel milk, car engine oil, etc., by home-based and small businesses. Fishing nets, though not so commonly used due to their unaffordable price, are repaired and maintained for longer time. Even single-use plastic bags are often used at least for a second time before disposal and were also made into handcrafts. Durable plastic bags such as packages of sugar and flour are collected and sold in the markets to be reused again for example as lining of roofs and walls of the wooden houses and shelters or to make smaller carrying bags used for different purposes. This may, to some extent, delay the disposal of these wastes into the environment for some time at least until it starts to degrade, therefore reducing the overall amount of plastic litter disposed into the environment.

During this study, the density of beach litter has decreased significantly subsequent to the first collections in all sites. While Dungonab Village showed gradual decrease in the abundance of beach litter and the rate of flux over the study time, other beaches exhibited a similar trend but with increase either in July (Shanaab, Cleaning Area) or October (DokanAlyamani and Mohamed Gol Jetty) with the commencement of fishing season. On the other hand, at the recreational beach of Toytoy, the abundance of beach litter and the rate of flux were comparatively higher in coincidence with suitable weather conditions allowing for picnicking. In this beach, the abundance of beach litter was higher in July and April compared to January and October.

This is corroborated with the apparent low rate of flux in DMNP throughout the study time. The present rates of flux revealed an inconsistency in the accumulation of beach litter over time at DMNP beaches, possibly due to local factors such as beach uses and oceanographic drivers playing role in marine litter distribution. The present beach litter rates of flux at DMNP were lower than those reported for the beaches of Corfu Island (N. Ionian Sea). There, the average net accumulation rate on all beaches was found to be $142 \pm 115 \mathrm{~N} / 100 \mathrm{~m} / 15 \mathrm{~d}$ [30] and that of the individual beaches was in the range of $77 \pm 46$ items $/ 100 \mathrm{~m} / 15 \mathrm{~d}$ to $190 \pm 96$ items $/ 100 \mathrm{~m} / 15 \mathrm{~d}$.

Against such background, it could be possible to suggest that the beach litter at DMNP is mainly of a local land-based origin and that beaches of DMNP are not a potential sink of beach or marine litter. Though further comprehensive investigation is required to affirm this information, it is of great importance for introduction of beach litter management measures in DMNP. A community-driven preventive management measure based on the cultural attributes of the local community such as the present reuse culture would greatly help in reducing the amount of litter disposed to the beaches of DMNP and in encouraging the community to 
further invent more reuse practices in favour of waste reduction.

\section{Conclusion}

Within the context of this study, we tend to consider that the abundance of cigarette butts and food wrapper could reasonably be used as indicators of socioeconomic changes in DMNP.

Coastal rural communities in remote areas in developing countries with low consumption of manufactured goods may have more valuation for materials which is manifested in their voluntary reuse behaviour. This is likely to contribute to lesser waste production and in the long term to beach litter management.

We also concluded that determination of the rate of flux and the clean coast index are preliminary reasonable indicators of marine litter dynamics and could be of importance to the evaluation of beach litter management.

The findings of the study indicated that the issue of beach litter in DMNP is still manageable, and application of preventive measures accompanied with awareness activities and investment in plastic recycling at the community level would further enhance and preserve the present status of beach cleanliness and encourage tourism activities.

However, it is highly recommended to establish and maintain beach litter monitoring programmes to generate evidence-based and scientifically sound information on litter source/sink, spatiotemporal abundance, and the rate of flux for national, regional, and global management levels.

\section{Data Availability}

The data used to support the findings of this study are available from the corresponding author upon request.

\section{Conflicts of Interest}

The authors declare that they have no conflicts of interest.

\section{Acknowledgments}

The authors acknowledge the funding of field work provided by the Regional Organization for Conservation of the Environment of the Red Sea and Gulf of Aden (PERSGA).

\section{References}

[1] N. J. Beaumont, M. Aanesen, M. C. Austen et al., "Global ecological, social and economic impacts of marine plastic," Marine Pollution Bulletin, vol. 142, pp. 189-195, 2019.

[2] D. Rodríguez-Rodríguez, "Littering in protected areas: a conservation and management challenge-a case study from the Autonomous Region of Madrid, Spain," Journal of Sustainable Tourism, vol. 20, no. 7, pp. 1011-1024, 2012.

[3] L. Polasek, J. Bering, H. Kim et al., "Marine debris in five national parks in Alaska," Marine Pollution Bulletin, vol. 117, no. 1-2, pp. 371-379, 2017.

[4] UN Environment, Marine Litter Socio Economic Study, United Nations Environment Programme, Nairobi. Kenya, 2017.
[5] M. Mannaart, A. Bentley, G. McCord, and J. J. Midavaine, Marine Litter at UNESCO World Heritage Marine Sites, KIMO International, Shetland, UK, 2019.

[6] T. Vlachogianni, "Marine Litter in Mediterranean coastal and marine protected areas-how bad is it," in A snapshot assessment report on the amounts, composition and sources of marine litter found on beaches, Interreg Med ACT4LITTER \& MIO-ECSDE, Athina, Greece, 2019.

[7] M. A. Kitto, C. Sambhu, and S. Al Deen, "Litter pollution on the coastline of Obhur, Saudi Arabia," in Proceeding of the 12th international conference on environmental science and technology, pp. 8-10, Rhodes, Greece, October 2011.

[8] A. Abu-Hilal and T. Al-Najjar, "Marine litter in coral reef areas along the Jordan Gulf of Aqaba, Red Sea," Journal of Environmental Management, vol. 90, no. 2, pp. 1043-1049, 2009.

[9] T. Al-Najjar and A. A.-W. Al-Shiyab, "Marine litter at (AlGhandoor area) the most northern part of the Jordanian coast of the Gulf of Aqaba, Red Sea," Natural Science, vol. 3, no. 11, pp. 921-926, 2011.

[10] A. H. Abu-Hilal and T. Al-Najjar, "Litter pollution on the Jordanian shores of the Gulf of Aqaba (Red Sea)," Marine Environmental Research, vol. 58, no. 1, pp. 39-63, 2004.

[11] T. Vlachogianni, T. Fortibuoni, F. Ronchi et al., "Marine litter on the beaches of the Adriatic and Ionian Seas: an assessment of their abundance, composition and sources," Marine Pollution Bulletin, vol. 131, pp. 745-756, 2018.

[12] D. Nachite, F. Maziane, G. Anfuso, and A. T. Williams, "Spatial and temporal variations of litter at the Mediterranean beaches of Morocco mainly due to beach users," Ocean \& Coastal Management, vol. 179, Article ID 104846, 2019.

[13] F. Asensio-Montesinos, G. Anfuso, and A. T. Williams, "Beach litter distribution along the Western Mediterranean coast of Spain," Marine Pollution Bulletin, vol. 141, pp. 119126, 2019.

[14] PERSGA/GEF, “Coastal Marine litter assessment guidelines for the Red Sea and Gulf of Aden," PERSGA, Jeddah, Saudi Arabia, PERSGA Guideline Number GD.0021, 2014.

[15] A. Cheshire, E. Adler, J. Barbière et al., "UNEP/IOC guidelines on survey and monitoring of marine litter," Regional Seas Reports and Studies No. 186, IOC Technical Series No. 83, UNEP, Nairobi, Kenya, 2009.

[16] R. Alkalay, G. Pasternak, and A. Zask, "Clean-coast index-a new approach for beach cleanliness assessment," Ocean \& Coastal Management, vol. 50, no. 5-6, pp. 352-362, 2007.

[17] U. Aytan, F. B. E. Sahin, and F. Karacan, "Beach litter on Sarayköy Beach (SE Black Sea): density, composition, possible sources and associated organisms," Turkish Journal of Fisheries and Aquatic Sciences, vol. 20, no. 2, pp. 137-145, 2019.

[18] I. R. Santos, A. C. Friedrich, and J. A. Ivar do Sul, "Marine debris contamination along undeveloped tropical beaches from northeast Brazil," in Proceedings of the III Congresso Brasileiro de Oceanografia-CBO, Fortaleza, Brazil, May 2008.

[19] N. Ríos, J. P. G. L. Frias, Y. Rodríguez et al., "Spatio-temporal variability of beached macro-litter on remote islands of the North Atlantic," Marine Pollution Bulletin, vol. 133, pp. 304-311, 2018.

[20] L. Godfrey, "Waste plastic, the challenge facing developing countries-ban it, change it, collect it?," Recycling, vol. 4, no. 1, p. 3, 2019.

[21] Ocean Conservancy, Building a Clean Swell: International Coastal Cleanup 2018 Report, Ocean Conservancy, Washington, DC, USA, 2018, https://oceanconservancy.org/wpcontent/uploads/2018/07/Building-A-Clean-Swell.pdf. 
[22] H. B. Jayasiri, C. S. Purushothaman, and A. Vennila, "Plastic litter accumulation on high-water strandline of urban beaches in Mumbai, India," Environmental Monitoring and Assessment, vol. 185, no. 9, pp. 7709-7719, 2013.

[23] M. A. Browne, M. G. Chapman, R. C. Thompson, L. A. Amaral Zettler, J. Jambeck, and N. J. Mallos, "Spatial and temporal patterns of stranded intertidal marine debris: is there a picture of global change?," Environmental Science \& Technology, vol. 49, no. 12, pp. 7082-7094, 2015.

[24] F. Galgani, D. K. A. Barnes, S. Deudero et al., "Executive summary," in Marine litter in the Mediterranean and Black Seas, F. Briand, Ed., CIESM Workshop Monograph No. 46, CIESM Publisher, Madrid, Spain, pp. 7-20, 2014.

[25] M. C. B. Araujo, J. S. Silva-Cavalcanti, and M. F. Costa, "Anthropogenic litter on beaches with different levels of development and use: a snapshot of a coast in Pernambuco (Brazil)," Frontiers in Marine Science, vol. 5, p. 233, 2018.

[26] A. A. Koelmans, "The Challenge: plastics in the marine environment," Environmental Toxicology and Chemistry, vol. 33, no. 1, pp. 5-10, 2014.

[27] J. R. Jambeck, R. Geyer, C. Wilcox et al., "Plastic waste inputs from land into the ocean," Science, vol. 347, no. 6223, pp. 768-771, 2015.

[28] A. E. Schwarz, T. N. Ligthart, E. Boukris, and T. van Harmelen, "Sources, transport, and accumulation of different types of plastic litter in aquatic environments: a review study," Marine Pollution Bulletin, vol. 143, pp. 92-100, 2019.

[29] C. Aydin, O. Guven, B. Salihoglu, and A. E. Kideys, "The Influence of land use on coastal litter: an approach to identify abundance and sources in the coastal area of Cilician Basin, Turkey," Turkish Journal of Fisheries and Aquatic Sciences, vol. 16, no. 1, pp. 29-39, 2016.

[30] M. Prevenios, C. Zeri, C. Tsangaris, S. Liubartseva, E. Fakiris, and G. Papatheodorou, "Beach litter dynamics on Mediterranean coasts: distinguishing sources and pathways," Marine Pollution Bulletin, vol. 129, no. 2, pp. 448-457, 2018. 